Thematic

Section

\section{Digita}

transformation

intelligent

manufacturing

and supply chain

management 4.0

\title{
Towards the Digitally-Enabled Multinational Inner Network (DEMIN)
}

\author{
A transformação digital das redes internas de multinacionais \\ Flavio Fisch ${ }^{1}$ (1), Afonso Fleury ${ }^{1}$ (1) \\ ${ }^{1}$ Universidade de São Paulo - USP, Escola Politécnica, Departamento de Engenharia de Produção, Grupo TTO \\ (Trabalho, Tecnologia e Organização), São Paulo, SP, Brasil. E-mail: flafisc@usp.br; acfleury@usp.br
}

How to cite: Fisch, F., \& Fleury, A. (2020). Towards the Digitally-Enabled Multinational Inner Network (DEMIN). Gestão \& Produção, 27(3), e5615. https://doi.org/10.1590/0104-530X5615-20

\begin{abstract}
The purpose of this paper is to contribute to the advancement of International Operations Management in the digital era. Theories and models that address how multinationals organize international operations were generated in the 1990s, a time when Kasra Ferdows wrote his HBR's seminal article "Making the Most of Foreign Factories". Despite the critiques, that simple and insightful model, a fruit of Ferdows' experience, remains as paradigm but must now be updated to become aligned to the features of the digital world. In this theory-building paper, we disclose how Digital Transformation will change the location, coordination, and role of the organizational units that constitute the multinational's inner international network (IIN). We first synthesize the digital trends into three statements that are contrasted with the assumptions of Ferdows' model, leading to a new taxonomy. We then display pieces of evidence collected from the recent literature in different management fields. This article brings new perspectives for the understanding of how multinationals reorganize their operations, now and in the future, in times of deglobalization accelerated by pandemics.
\end{abstract}

Keywords: DEMIN; International Manufacturing Network; Inner International Network; Site role; Digital transformation.

Resumo: O objetivo deste texto é contribuir ao avanço do conhecimento sobre Gestão de Operações Internacionais na era digital. As teorias e modelos que tratam de como as multinacionais organizam suas operações internacionais foram gerados nos anos 1990, uma época em que Kasra Ferdows escreveu seu artigo seminal na revista HBR intitulado "Making the Most of Foreign Factories" (Tirando o máximo das fábricas estrangeiras). Apesar das críticas, esse modelo simples e inspirador, fruto da experiência de Ferdows, ainda permanece como um paradigma, mas deve ser atualizado para se alinhar às características do mundo digital. Neste texto de construção de teoria, nós descrevemos como a transformação digital vai modificar a localização, coordenação e papel das unidades organizacionais que constituem a rede internacional interna das empresas multinacionais. Primeiro, nós sintetizamos as tendências em três enunciados que são contrastados com os pressupostos do modelo de Ferdows, revelando uma nova taxonomia - a RIMDC - Rede Interna Multinacional Digitalmente Capacitada. Em seguida, nós mostramos evidências coletadas da literatura recente em diferentes campos de gestão. Este artigo traz novas perspectivas para o entendimento da forma na qual as multinacionais reorganizam as suas operações, hoje e no futuro, em tempos de desglobalização acelerada pela pandemia.

Palavras-chave: RIMDC; Rede Interna de Manufatura; Rede Internacional Interna; Papel da planta; Transformação digital.

Received Mar. 28, 2019 - Accepted Dec. 30, 2019

Financial support: This research was realized with support from Coordenação de Aperfeiçoamento de Pessoal Superior - CAPES Brasil (Flavio Fisch) and the CNPq - Conselho Nacional de Desenvolvimento Científico e Tecnológico (Afonso Fleury).

This is an Open Access article distributed under the terms of the Creative Commons Attribution License, which permits unrestricted use, distribution, and reproduction in any medium, provided the original work is properly cited. 


\section{Introduction}

Digital Transformation has touched almost every aspect of human life (Schwab, 2017). Its impacts on Operations Management have been significant, merging the physical and digital worlds, creating new possibilities to integrate machines, men, and organizations (Kagermann et al., 2013; Schwab, 2017). The digital revolution is expected to have a great impact on firms' organization in general. In what concerns multinational enterprises and their international operations, digital technologies are already changing subsidiaries' configuration and coordination, and consequently, plant roles.

The literature that addresses the above issues is based on two seminal papers: Kasra Ferdows' (1997) article on plant roles and Shi \& Gregory's (1998) article on International Manufacturing Networks.

Kasra Ferdows' taxonomy, published in the Harvard Business Review, was a simple, extremely insightful, and powerful model, resulting from the author's experience mainly and not developed for academic validation. Many scholars tried to replicate (Vereecke \& Van Dierdonck, 2002), enhance (Cheng et al., 2011) or even criticize the model (Meijboom \& Vos, 2004), resulting in supporting literature that justifies the model's wide acceptance in the OM field. Demeter (2017) and Feldmann \& Olhager (2013) provide excellent summaries of the literature based on the model proposed by Ferdows (1997). Shi \& Gregory (1998) elaborated the pioneering model to describe the IMN - International Manufacturing Network - using two factors, the first being configuration - the geographical location of all plants - and the second being coordination, the distribution of activities across plants. The relation between that model and Ferdows' plant role model is explored by Cheng et al. (2011) when they study what happens to an IMN configuration and coordination when one of its plants has its role changed.

Despite the vast amount of literature that was generated for the two research subjects - International Operations Management and Digital Transformation - their intersection is still very scarce. Searches in the Scopus database using terms related to Digital Transformation and Global Operations literature count well over 1,000 articles each, while only a handful of articles cover both areas simultaneously, among them two editorials that urge for more academic works to bridge the two themes (Brennan et al., 2015; Strange \& Zucchella, 2017). In this study, we will explore the limits of Ferdows' taxonomy and build a new analytical model more apt to describe the features of international operations in the digital era - the Digitally-Enabled Multinational Inner Network (DEMIN). We will adopt the term Inner International Network (IIN) for the collection of home and foreign production units of a multinational enterprise, assuming that this term is broader than International Manufacturing Network, thus reflecting the integration of different functions that characterize the Digital Transformation.

We will develop brief reviews of both International Operations Management and Digital Transformation as subjects and then use the few reference articles that attempt to bridge International Operations Management and Digital Transformation as a base to our arguments.

We will adopt the concept of digital maturity to indicate the degree of advancement of a firm regarding Digital Transformation. Frequently cited in the academic literature and widely used in the commercial literature, the German Academy for Technology - Acatech's Industrie 4.0 Maturity Index - uses four dimensions to evaluate the digital maturity of an organization, two of them related to technologies - resources 
and information systems - and two related to the organization - organization design and culture (Schuh et al., 2017). That signalizes that technology alone is not enough to improve digital maturity, but rather requires an organizational change, is widely acknowledged in the academic literature (Schuh et al., 2017; Schumacher et al., 2016).

The remainder of the article proceeds as follows: In Section 2 we build the theoretical reference of International Operations Management focusing IINs, foreign plant roles, Digital Transformation in terms of its enabling technologies, and the intersection of these two well-documented areas in the literature that support our Statements; in Section 3 we build the analytical model, the Digitally-Enabled Multinational Inner Network (DEMIN) and a new taxonomy for plant roles in the digital era; Section 4 brings evidence from the academic and business literature to support the Statements, model and taxonomy herein presented; and in Section 5 we conclude the article with our main contributions, limitations, and future research opportunities.

\section{Literature review}

\subsection{Configuration and coordination of IINs in OM}

International Operations Management is approached from two perspectives. The internal, inner network dubbed IIN - inner international network - associates structural and infrastructural decisions at the plant level with configuration and coordination issues for the network level, thus providing a firm internal perspective whereas value networks fit better to analyze end-to-end supply chain decisions from a firm's external perspective (Demeter, 2017; Rudberg \& Olhager, 2003). In this paper, we use the internal - IIN - perspective to analyze International Operations Management at both the plant and network levels. We use the definition from Cheng et al. (2015, p. 393) for the IIN: "[...] a coordinated aggregation (network) of intra-firm plants located in different places". We also define manufacturing activities broadly as those related to production or service delivery, Research and Development (R\&D), logistics, marketing, sales, and administrative support functions, in line with Fleury \& Fleury (2012) and Rugman et al. (2011). A plant may execute one or several of these activities, according to this definition. Service delivery is also included in the definition to cope with servitization, a phenomenon that will be later discussed in section 3.1.2.

Cheng et al. (2015) identify two main units of analysis in their literature review on IINs - the IIN and the plant. The IIN-level literature is based on a model proposed by Shi \& Gregory (1998) that is characterized by two dimensions, the geographic dispersion of their plants, or the IIN's configuration, and the degree of centralization of activities, or the IIN's coordination. The main advantage of the IIN-level approach is that it offers a network-wide perspective of the potential advantages and capabilities of the entire network, while the plant-level approach allows researchers to evaluate different characteristics of individual plants that form the IIN (Cheng et al., 2015). In the next paragraphs, we describe the plant-level approach to study IINs.

In his seminal article, Kasra Ferdows (1997) proposes a framework and plant role taxonomy that is widely recognized in the OM literature, as presented by Demeter (2017) in her literature review of past, present, and future of OM research, and by Feldmann et al. (2013) when they discuss the effect of a plant role change in a manufacturing network configuration and coordination. Ferdows (1997) argues that the configuration of an IIN is determined by the Strategic reason for locating each of the 
participating plants, while the IIN coordination is determined by the competences or activities that each plant executes. Different combinations of these two factors determine the plant role within the IIN. Vereecke \& Van Dierdonck (2002) use case studies to test and validate the model, proposing a few adjustments to Ferdows' taxonomy. Meijboom \& Vos (2004) review the literature on "site competence" to build a precise definition of the term originally used by Ferdows (1997) and test it using cases from Dutch-owned plants in Poland and Hungary. Feldmann \& Olhager (2013) also discuss the two factors used by Ferdows (1997) to build his taxonomy, providing a comparison chart of several papers that provide empirical support to the model.

The first factor addressed by Ferdows (1997) is the strategic reason for site location. The author lists three main reasons that justify the location of a plant. The first one is access to low-cost production sites, a major driver for offshoring operations in the second half of the $20^{\text {th }}$ century (Kinkel, 2012). The second is the access to knowledge and capabilities, a driver that gained impulse with the rise of emerging market multinational enterprises (Fleury \& Fleury, 2012). Finally, the third reason identified by Ferdows (1997) is the proximity to markets. Feldmann \& Olhager (2013), Feldmann et al. (2013), and Vereecke \& Van Dierdonck (2002) are some authors that empirically test and validate the three strategic reasons for Site location proposed by Ferdows (1997).

Regarding "access to knowledge and capabilities", Ferdows (1997) proposes a hierarchy of activities that foreign plants can execute, calling them "competences". The lowest level of competence is "production" while the upper level is "global hub for product or process knowledge". Intermediate levels consider competences like technical process, procurement, logistics, supplier's development, process recommendations for development and improvement, product development, and global market supply. That hierarchy of competences is criticized in several ways: the terms "activity" and "competency" are used interchangeably, the classification lacks empirical evidence, and there are plants that retain higher responsibilities without necessarily executing lower ones (Vereecke \& Van Dierdonck, 2002). Concomitantly, other empirical evidence is gained through case research and interviews with academics and practitioners from actual IINs (Feldmann \& Olhager, 2013; Meijboom \& Vos, 2004; Vereecke \& Van Dierdonck, 2002). In the end, even if the hierarchy of activities varies from author to author, the first level is always production, followed by local management, whereas development for the entire network (Feldmann \& Olhager, 2013 ) is always at the highest-level competencies. We will use the term "activity" for actual tasks executed by the site, while "competency" will be used for an existing capability at the Site that may be at use or at the disposal of the IIN to be used, in line with the description provided by Vereecke \& Van Dierdonck (2002).

Based on the combination of the strategic reason to locate and the capabilities found in a plant, Ferdows (1997) presents a taxonomy of plant roles composed of six different types, depicted in Figure 1. 


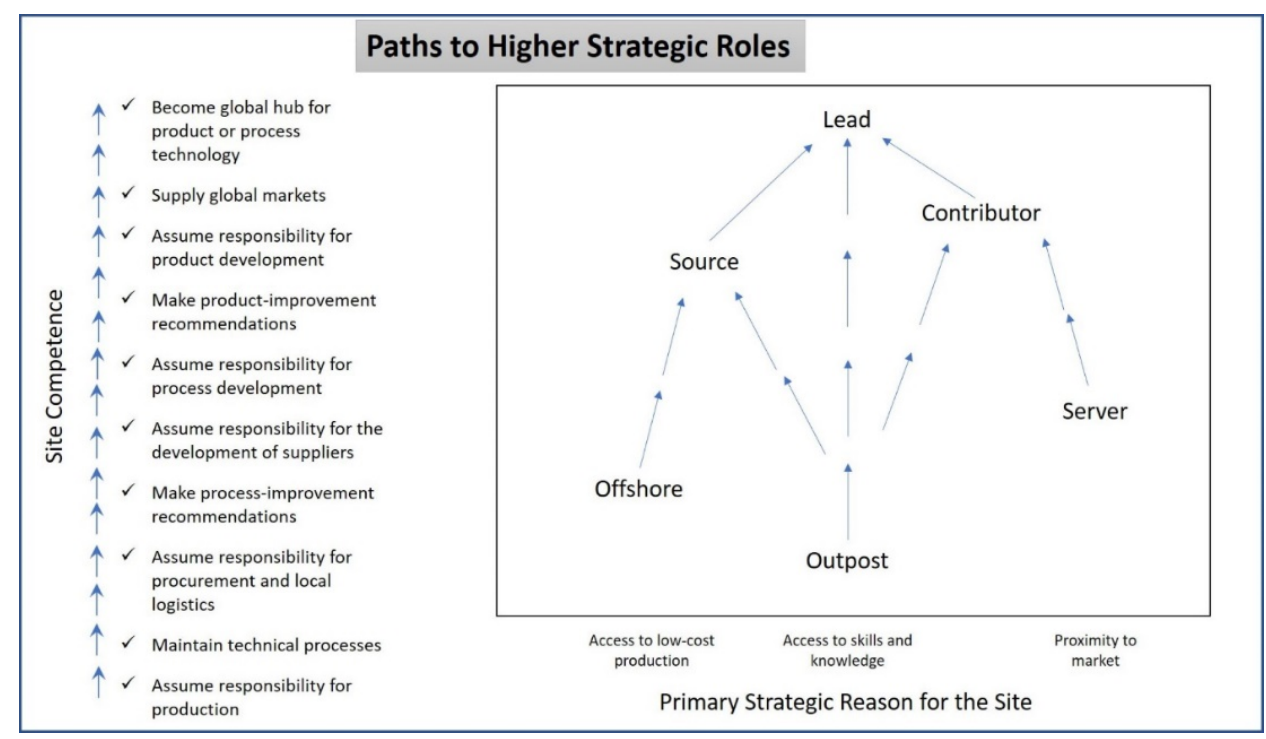

Figure 1. Ferdows model for plant roles. Source: Ferdows (1997).

The types of plants that have a primary strategic reason to locate based on access to low-cost production are Offshore and Source Plants (Ferdows, 1997). Offshore Plants assume responsibility for production only. They consist of intensive labor and local production management activities. All other activities like procurement of materials, production planning, product, and process development, are executed elsewhere in the IIN. The disadvantages of remote coordination, like delays in communication and decision-making, and higher inventories are compensated by the lower cost of production. By progressively assuming other responsibilities like process, procurement, logistics, simple process, and even product improvement recommendations, Offshore Plants can upgrade to Source Plants. This arrangement overcomes the coordination disadvantages of Offshore Plants at the cost of expensive resources at Source Plants (Ferdows, 1997).

Server and Contributor Plants locate next to markets. They differ from the low-cost operations in the sense that they are in touch with the markets they serve, therefore more sensitive to local adjustments to products (Ferdows, 1997). Server Plants typically focus on local production but generally have some freedom to adapt products to local markets. Contributor Plants locate in strategic markets, have proximity with the leader of the IIN, usually contributing to the product, process, and system upgrades.

Outpost and Lead Plants seek access to skills and knowledge. They locate in knowledge-intensive areas, close to universities, suppliers, and technical centers. Outposts always have a secondary reason to locate because all plants are required to have production activities to belong to the IIN This is a characteristic of models built in the Industry 3.0 environment.

The last plant type in the model, the Lead Plant, has the highest level of Site competence and activities, being global hubs for process and product knowledge (Ferdows, 1997).

Industry 3.0 sped the internationalization of firms and the formation of complex and dynamic IINs formed by plants with roles described by Ferdows' model in the 1990's and early 2000's. Despite the informatization and incipient connectivity of Industry 3.0 systems at the plant level, there were still severe limitations to real-time data flow and 
analysis at the IIN level that would have to wait for a further industrial revolution to be overcome and become a reality.

\subsection{Some features of digital technology as they may influence IINs}

The starting point of Digital Transformation, or the so-called fourth industrial revolution or Industry 4.0, can be traced back to the Hannover Messe in Germany back in 2011, where the term Industrie 4.0 was first coined (Kagermann et al., 2013). It is related to the popularization of the internet and the constant capacity increase of generating, processing, transmitting, storing, and analyzing data ever since. Together with technological, social and political developments in the world during this period, this incipient field of research has generated a huge body of literature, well described in several literature reviews (Alcácer \& Cruz-Machado, 2019; Liao et al., 2017, 2018; Rodrigues et al., 2016). Also relevant is the number of articles that propose models to measure the maturity level of Industry 4.0 (Schumacher et al., 2016). A widely used of such models was proposed by the German Acatech, the Industry 4.0 Maturity Index (Schuh et al., 2017).

Digital transformation, Industry 4.0, and the fourth industrial revolution are widely used terms to denote recent developments that are changing the face of the world as we know it in the same way previous industrial revolutions did in the past (Frank et al., 2019a; Schwab, 2017). The first industrial revolution took place by the end of the $18^{\text {th }}$ century with the invention of the steam machine that moved the industry from the home to the factory environment. The second industrial revolution, or Industry 2.0, introduced the electrification, the use of the production line and marked the birth of Operations Management through Frederick Winslow Taylor and his "Principles of Scientific Management in 1911 (Taylor, 1998), later improved by Taiichi Ohno with the Toyota Production System (Yin et al., 2018). The third industrial revolution, also known as Industry 3.0, introduced automation and digitalization that greatly improved productivity. Robots, computer systems, and early internet tools characterize this revolution (Liao et al., 2018; Rodrigues et al., 2016; Schwab, 2017).

The fourth industrial revolution integrates the physical, digital and biological worlds (Schwab, 2017). It is also known as Industry 4.0, although the latter does not encompass the biological integration of worlds (Barbosa et al., 2018; Drath \& Horch, 2014; Lichtblau et al., 2015). One of its distinctive features against the third industrial revolution is the level of systems integration. While in Industry 3.0 system integration was slow with manual data handling and a hierarchical structure, in Industry 4.0 systems are integrated real-time using automated data handling, cloud repositories and a network structure, described as Reference Architecture Model Industry 4.0 - RAMI4.0 by the norm IEC 63088 (Adolphs et al., 2015).

Several technologies combine to enable Industry 4.0, like cheap sensors to collect data, the Internet of Things and Services to transmit it, cloud computing to store a large amount of data, big data analysis and artificial intelligence that enable automated simulation, forecast and decision making (Alcácer \& Cruz-Machado, 2019). Together, they allow firms to build digital shadows or twins that represent the physical systems. Digital and physical counterparts instantly update each other, forming a Cyber-Physical System (CPS) (Kagermann et al., 2013; Schwab, 2017; Strange \& Zucchella, 2017). With proper data generation, cloud storage and big data analysis, business models, product and service offerings, innovation, production, supply chain, sales, 
and after-sales systems are interconnected and integrated in real-time, thanks to CPS and digital platforms (Alcácer \& Cruz-Machado, 2019).

The integration of systems that enable CPS, people, and different organizations to work together is the digital platform. Gawer (2014) proposes three types of digital platforms depending on their use: a) Internal platforms are used within the firm to meet the needs from people and systems at different levels, plants, and functions inside the IIN of the firm; b) economic or supply chain platforms that support the business ecosystem formed by suppliers, customers, clients, and end-users; and c) industrial platforms, used to build innovation ecosystems, intended for research and development of products, services, systems and applications, open to any contributor like research institutes, universities, complementors, users and supply chain partners. Digital platforms allow a faster and broader involvement of organizations and ecosystems for value creation and capture (Gawer, 2014; Vasconcelos Gomes et al., 2018).

\subsection{Merging two bodies in the literature - International Operations Management and Digital Transformation}

International Operations Management and Digital Transformation are well-researched subjects, but their intersection is scarce and underexplored. Using Scopus database searches, we identified 2,777 articles related to International Operations Management and IINs, and 4,790 articles on Digital Transformation and Industry 4.0. Relevant literature reviews can be found in each of the researched areas (Alcácer \& Cruz-Machado, 2019; Demeter, 2017; Liao et al., 2018; Rodrigues et al., 2016). They were used as sources to build the theoretical reference in this work. The combination of the two separate searches above mentioned provides only seven results, even though Kagermann et al. (2013) envision an integrated network of plants in their seminal work that coined the term "Industrie 4.0". Three of them are out of the scope of this paper. We use the other four - Strange \& Zucchella (2017) with 66 citations, Brennan et al. (2015) with 45 citations, Telukdarie et al. (2018) with 29 citations and, Seino (2019) - plus Adolphs et al. (2015) as a starting point for areas where Digital Transformation interacts with International Operations Management. The five articles reveal three trends that we further explore in this paper: a) Centralization (Adolphs et al., 2015; Telukdarie et al., 2018); b) servitization (Brennan et al., 2015; Seino, 2019); c) relocation (Brennan et al., 2015; Strange \& Zucchella, 2017). Using the set of five articles and relevant literature reviews from the interest areas, we develop the Statements for our model.

\subsubsection{Centralization}

Digital technologies enable firms to integrate IIN management activities since these can be carried in the virtual environment of a CPS while the execution takes place elsewhere, for example on the floor of each plant. The networked nature of systems integration eliminates delays that did not allow effective real-time integration in the past (Adolphs et al., 2015).

Telukdarie et al. (2018, p. 323) propose an "[...] integrated multinational total business solution" that integrates the entire IIN with real-time visibility, response, optimization, forecasting and decision-making capabilities, in line with the evolutionary stages of visibility, transparency, predictive capacity, and adaptability mentioned by 
Schuh et al. (2017) in the formulation of the digital maturity index. Other advantages of such a solution, according to Telukdarie et al. (2018) are the lower administration and operational costs, higher operational efficiency, lower level of mistakes generated by data errors, and higher standardization that allows the fastest global incorporation of upgrades and changes. By simulating the repair of a machine breakdown, Telukdarie et al. (2018) estimate a 3-fold time reduction between a fully automated Industry 4.0 plant and a manual Industry 2.0 , and a $20 \%$ reduction for as to Industry 3.0 facility.

Adolphs et al. (2015) underline the optimization of research and development (R\&D) processes as a key benefit from the Digital Transformation through the life-cycle dimension of the model. Function integration is obtained across the life-cycle of a product when R\&D provides standards and data to manufacturing systems in real-time as soon as a product type is developed, tested and validated as well as when R\&D uses real-time data on production parameters, product performance in the field, and customer raw data to identify process and product design issues, or emerging trends on customer preferences, thanks to technologies like loT, cloud computing and big data analysis (Adolphs et al., 2015).

The higher functional integration suggests that R\&D centers are now a part of IINs, independent of their co-location with manufacturing Sites. Moreover, with Digital Transformation, R\&D centers gain the capability to spread and intensify research and development activities by coordinating digital industry platforms that include both internal and external partners that form stronger and broader innovation ecosystems capable of creating more value to the firm (Vasconcelos Gomes et al., 2018; Gawer, 2014).

Ferdows' model considered R\&D activities only those that were part of the manufacturing process. Therefore, no stand-alone $R \& D$ sites were considered in the model. The previous arguments suggest that Digital Transformation promotes the centralization of both production and R\&D management, leading to Statement 1.

Statement 1 - Increasing digital maturity enables firms to centralize management functions in a specific foreign location for the entire IIN thus leading to changes in configuration, coordination, and plant roles.

\subsubsection{Servitization}

Although a relatively recent phenomenon, servitization counts with a rich academic literature. A search of the "serviti?ation" term in Scopus database returns 579 articles. Tim Baines, the most frequent author in servitization, has authored or co-authored literature-review papers on servitization that received over 2000 citations according to the Scopus database (Baines et al., 2007, 2009, 2017; Lightfoot et al., 2013).

The term "Servitization" was first coined by Vandermerwe and Rada (1988) and is studied by different communities like Services Marketing, Services Management, OM, Product-Service Systems and Service Science, the latter having evolved from Information Systems, according to the literature review published by Lightfoot et al. (2013). Lightfoot et al. (2013, p. 1412) define servitization as "[...] the innovation of a manufacturing organization's product and service offering that delivers value in use". In OM, Brennan et al. (2015) describe servitization as an end-to-end approach that starts with R\&D and affects all steps through after use of product or service.

Digital transformation has significantly improved the speed of servitization transformation (Baines et al., 2020). Technologies like loT, cloud computing, and big 
data analysis allow firms to offer a range of advanced services instead of selling products (Frank et al., 2019b). In this type of business model, IINs should include sites that provide services in addition to the traditional manufacturing plants. Products in the field are monitored in real-time by control centers, while service is provided locally. (Baines et al., 2009; Seino, 2019; Visintin, 2014). This IIN configuration and coordination mode shortens inspection and repair times, lowers service costs and improves the reliability and productivity of the entire system (Baines et al., 2020; Govindarajan \& Immelt, 2019; Martinez et al., 2010), and is also in line with the findings from Casella \& Formenti (2019) about FDI investment in the digital era. The integration of product and service offerings requires a network that considers both types of operations, something not considered in the model proposed by Ferdows. The discussion above leads to Statement 2.

Statement 2: Increasing digital maturity favors the incorporation of services offerings abroad with a corresponding change in the IIN's configuration, coordination, and its plant roles.

\subsubsection{Relocation}

A typical phenomenon from the third industrial revolution, offshoring production to low wage countries gained drive in the 1990s and early 2000s but suffered a reduction since the 2008 crisis (Kinkel, 2012). Reshoring, on the other hand, is associated with the correction of a failure to offshore but may also be associated with a strategical decision in the evolution of multinational firms (Barbieri et al., 2018; Brennan et al., 2015; Kinkel, 2012). Ancarani et al. (2019) analyze backshoring initiatives from European firms in the light of Digital Transformation, concluding that the need for higher customization, flexibility, and agility to respond to customers' requirements is a key strategic reason, in line with Brennan et al. (2015). Digital technologies such as 3-D printing and collaborative robots play an important role to counterbalance low-cost labor and enable production reshoring through innovative business models (Ancarani et al., 2019; Barbieri et al., 2018; Brennan et al., 2015). Allied to digital platforms that allow product customization by the end-user, these technologies can be brought closer to markets, reducing cost and delivery time (Brennan et al., 2015; Strange \& Zucchella, 2017).

Therefore, relocating production closer to markets improve the IIN's capability to capture the tacit market and operational knowledge for the IIN, besides quickly adjusting to changing customers' requirements (Bertola \& Teunissen, 2018).

On the other hand, low-cost driven sites lose their capability to acquire new capabilities and upgrade, as foreseen by Ferdows' model. Higher-order activities now take place at the specific foreign location described in Statement 1, thanks to the tools and digital technologies provided by higher digital maturity (Adolphs et al., 2015).

Statement 3: Increasing digital maturity favors proximity to market as a strategic reason to locate foreign plants, providing higher agility and flexibility to attend the customers' demands, contrary to low-cost production sites that lose capabilities and the possibility to upgrade. 


\subsubsection{Conclusion}

The three Statements above call our attention to the changes in plant roles, driven by technologies from the Digital Transformation in ways that were not foreseen by Ferdows' model. When a single plant or an entire IIN increase their digital maturity, they open new avenues that may promote a change in the plant's strategical reason to locate, and in the activities executed by that plant, leading to a change in its role inside the IIN. Firms will change their IIN configuration and coordination, closing operations that do not fit the new model, opening new ones with specific activities enabled by digital technologies like depicted in Figure 2.

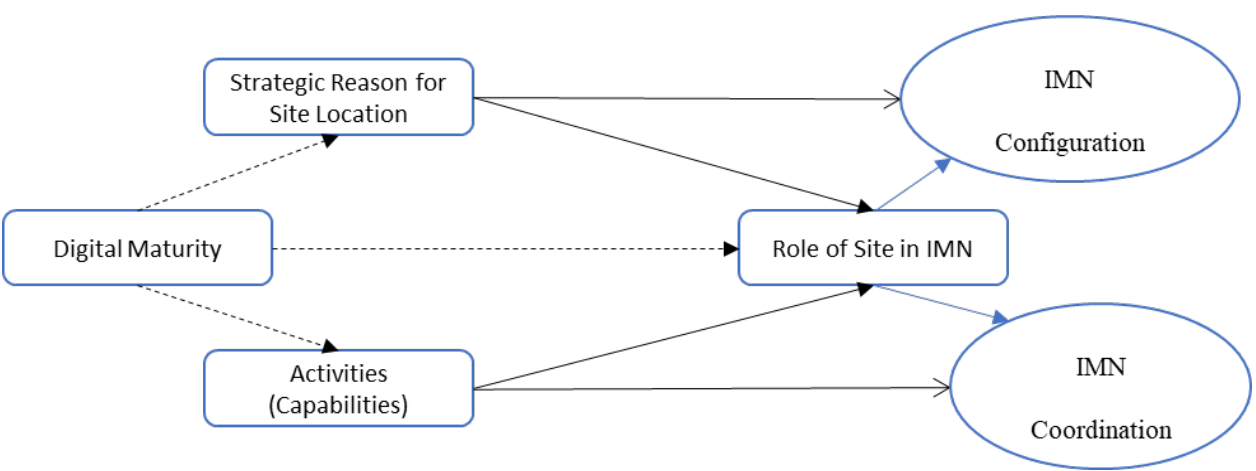

Figure 2. Determinants of plant role in the digital era. Source: Authors.

While an IIN has a low digital maturity, Ferdows' model still prevails and the firm will organize its IIN accordingly, whereas as soon as one single plant or the entire IIN move into high digital maturity, the logic used will change according to the Statements developed in this paper.

\section{The DEMIN model (Digitally-Enabled Multinational Inner Network model)}

\subsection{Analytical model}

The statements 1,2 , and 3 presented in the previous section provide a basis for us to review the configuration and coordination of the IIN and the roles of its sites considering both traditional factors, (a) the strategic reason to locate; and (b) the activities, and a third factor; (c) the digital maturity of the plant. In this context, the roles of plants with low digital maturity, i.e. Ferdows' model, were presented in Figure 2.

Statement 1 suggests that higher digital maturity allows activities to be planned and controlled from a specific location (either at home or foreign), while executed across the IIN. Two new types of organizational units emerge: COORDINATION CENTERS managing CPS for activities like planning or maintenance for the entire IIN, or real-time monitoring of products and services in the field, and REGIONAL R\&D CENTERS, managing innovation platforms for the IIN using real-time data from plants, products in the field, and customers.

Statement 2 describes how higher digital maturity can boost servitization The literature suggests that services supported by digital technologies should be 
managed from centralized sites, the Coordination Centers above mentioned and executed by units located close to clients and markets, a new type of site not foreseen by Ferdows, the LIGHTWEIGHT SERVICE CENTER.

Statement 3 suggests a shift in the trend to locate plants in low-cost environments (offshoring) and an increase in the tendency to relocate plants closer to markets (Backshoring). The tradeoff between remote delay management and local higher-cost resources no longer exists in the digital era. Systems updated in real-time allow multinationals to manage low-cost operations from their Coordination Centers. Offshore and Source plants lose capabilities and become PRODUCTION CENTERS, sites that produce at low cost, but are managed by the multinationals' Coordination Centers.

Like the Production Centers, the plants that are closer to markets also have some of their activities transferred to Coordination Centers. Notwithstanding, they gain relevance in the digital era for two reasons. The first and most obvious is the proximity to clients. Plants that are located close to markets are capable to capture the tacit knowledge about clients and local operations and to contribute with other IIN plants to improve products, services, processes, and digital systems. The second reason is that clients and customers require products and services customized to their needs. This requires higher flexibility and agility attainable through digital technologies. By focusing on their original higher-order capabilities as described by Ferdows, CONTRIBUTOR plants in the digital era will benefit from proximity to markets and higher connectivity to fill their role, increase productivity, and reduce costs. On the other hand, Server Plants may either upgrade to Contributors due to their proximity to clients or become small CUSTOMIZATION CENTERS, a new type of unit that is lightweight, flexible, and capable to quickly adjust production to the clients' needs.

Higher digital maturity promotes a functional integration that removes the traditional separation of R\&D, production, and service networks. The high network integration that takes place inside the multinational enterprise configures the Digitally-Enabled Multinational Inner Network (DEMIN). Figure 3 displays the evolution towards the DEMIN, which is detailed in the subsequent paragraphs. Table 1, at the end of the section, presents a comparison between the Ferdows' and the DEMIN models. 


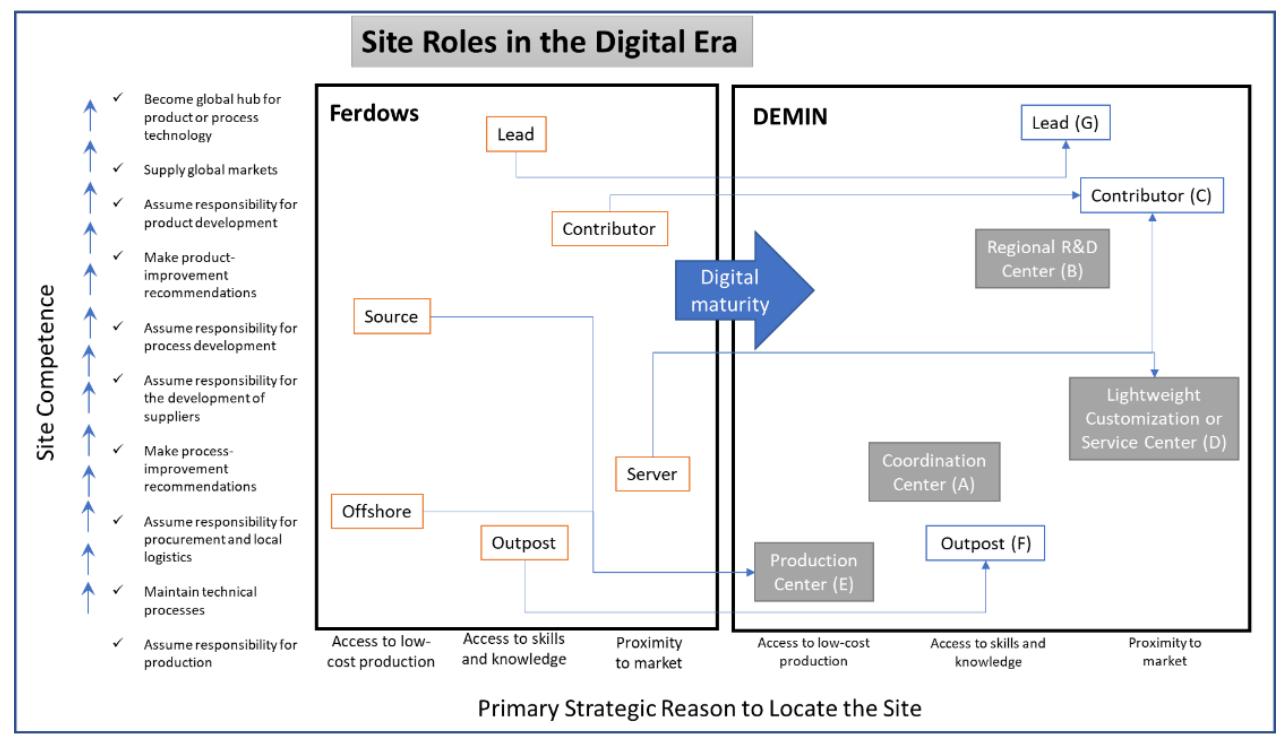

Figure 3. Evolution of plant roles in the digital age. Source: Authors.

(A) The location of COORDINATION CENTERS depends on the availability of local capabilities and knowledge to enable them to take responsibility for specific management activities for the IIN using CPS and digital platforms. There is little or no production or customer service execution at these sites and so they may be co-located or stand-alone. Since they can operate from any foreign location, they tend to locate where the needed capabilities are available at the lowest cost. Ferdows' model does not consider the existence of this type of site because before the digital era the necessary technologies were not yet commercially available, and service was usually a separate function.

In manufacturing, Coordination Centers have real-time visibility of material flows, inventories, and capacities for the IIN, optimizing the procurement, production, and maintenance planning and scheduling as well as logistics management activities for the network, a clear advantage of high versus low digital maturity networks. In services, the use of CPSs allows Coordination Centers to monitor the equipment or service in the field, anticipate service needs and manage the activities of the Lightweight Service Centers using the digital internal platform of the IIN. Corporate administrative systems such as Human Resources Management, Finance, or ICT services of the IIN can also be managed by Coordination Centers. The use of Coordination Centers provides standard systems to the entire DEMIN.

(B) The REGIONAL R\&D CENTERS are the second type of Site added to the model. They are included because of the higher integration of R\&D and production functions, as explained by the life-cycle integration dimension of the RAMI4.0 model (Adolphs et al., 2015). Its strategic reason to locate is the availability of specific knowledge available in innovation ecosystems. Proximity to strategic markets may also be a determinant for the location of these centers. Their activities are to research and develop products, services, processes, and systems for the IIN. There might be a tendency to co-locate Regional R\&D Centers with manufacturing plants as proximity fosters broader inter-function collaboration (Brennan et al., 2015), but they can still operate as stand-alone units, though now connected to manufacturing sites through CPS. The use of digital industry platforms managed by the R\&D 
centers enables firms to broaden their innovation ecosystems by allowing a higher number of collaborators to join it from inside and outside the IIN;

(C)CONTRIBUTOR Plants in the DEMIN model have a similar role as in Ferdows'. Some or all the lower-level management activities are transferred to the Coordination Center, releasing the Contributor Site to focus on higher-order activities. Contributor Plants enjoy high connectivity to other plants of the DEMIN, supporting or leading the development of products, processes, and systems. The proximity to the market is their main strategic reason to locate. They use this advantage to collect tacit data about the customers and the market they serve. Focusing on higher-order activities, Contributor Plants also require skills and knowledge to fulfill their activities. By increasing its digital maturity, the Server Plant from Ferdows evolves in two different ways. It is important to stress that high volume Server Plants may upgrade to become Contributor Plants since it is unlikely that sites with so much skill, data, and knowledge would simply be downgraded. Smaller volume Server Plants may specialize and become Customization Centers that are highly flexible operations, described in the next paragraph;

(D) LIGHTWEIGHT SERVICE AND CUSTOMIZATION CENTERS should be located close to markets where services or customization will take place. Their activities consist of executing services or production to order according to specific clients' preferences. They differ from the Ferdows'Server Plants because they are very agile and flexible, connected to the IIN. Their proximity to customers also allows these units to contribute with the IIN (Reginal R\&D) to improve products, systems, and the quality of services provided. In the cases where Server Plants increase their digital maturity and specialize to attend small volume customers' requirements, they can become agile and flexible Lightweight Customization Centers;

(E) The need to balancing low-cost and remote management for Offshore Plants, and high-cost local management for Source Sites disappears. While PRODUCTION CENTERS maintain production activities only, all higher-order activities previously executed at the Source Plants will be transferred to Coordination Centers. By increasing the digital maturity of the IIN expensive resources are no longer needed at Source Plants to coordinate higher-order activities, while the extra costs related to remote management of Offshore Plants are overcome with CPS and digital platforms. The maintenance of Production Centers will be only justified by low costs, so they become at risk of closure or may face severe difficulties to upgrade within the network;

(F) DEMIN's OUTPOST is equivalent to Ferdows' Outpost Plant, the sole difference being that the DEMIN's Outpost does not require a secondary role as a manufacturing site since it can communicate in real-time with the other units through digital platforms. They might upgrade to customization centers, in case their activities eventually incorporate manufacturing, or to Regional R\&D Centers, in case they acquire R\&D capabilities and capture higher-order activities;

(G)Finally, LEAD units in our model, like Ferdows', is described as the global hub of knowledge that determines the IIN's objectives, strategy, products, services, and processes. When the digital maturity of the IIN increases, the Lead sites may transfer some of its lower-level management activities to Coordination Centers, releasing resources to focus on higher-order activities. Regional R\&D Centers and Contributor Plants may upgrade to Global Leaders if they aggregate enough capabilities to take global responsibilities for the multinational enterprise. 
A Regional R\&D Center may become a global leader in a specific technology, while a Contributor Plant may assume a leadership role in certain production systems for the firm.

To summarize, Table 1 presents a comparison between the DEMIN and Ferdows' models.

Table 1. Ferdows $\times$ DEMIN.

\begin{tabular}{|c|c|c|c|}
\hline $\begin{array}{l}\text { Strategic } \\
\text { Reason to } \\
\text { Locate }\end{array}$ & FERDOWS & DEMIN & $\begin{array}{l}\text { COMPARISON AND } \\
\text { CHARACTERISTICS }\end{array}$ \\
\hline \multirow[b]{2}{*}{$\begin{array}{l}\text { Low-Cost } \\
\text { Production }\end{array}$} & Offshore & \multirow[b]{2}{*}{$\begin{array}{l}\text { Production } \\
\text { Center }\end{array}$} & \multirow{2}{*}{$\begin{array}{l}\text { The Production Center is remotely } \\
\text { coordinated by the Coordination Center } \\
\text { in real-time, eliminating the dilemma of } \\
\text { having delayed remote coordination } \\
\text { (offshores) or in-site high-cost resources } \\
\text { (servers) }\end{array}$} \\
\hline & Server & & \\
\hline \multirow{4}{*}{$\begin{array}{l}\text { Access to } \\
\text { Knowledge } \\
\text { and } \\
\text { Capabilities }\end{array}$} & Outpost & Outpost & $\begin{array}{l}\text { The Outpost of the DEMIN model does } \\
\text { not require in-site manufacturing, as it is } \\
\text { connected in real-time to the rest of the } \\
\text { network }\end{array}$ \\
\hline & & $\begin{array}{l}\text { Coordination } \\
\text { Center }\end{array}$ & $\begin{array}{l}\text { A new type of Site that manages } \\
\text { production or service management } \\
\text { activities for the IIN. }\end{array}$ \\
\hline & & $\begin{array}{l}\text { Regional R\&D } \\
\text { Center }\end{array}$ & $\begin{array}{l}\text { Included in the DEMIN model due to the } \\
\text { higher functional integration of R\&D and } \\
\text { production }\end{array}$ \\
\hline & Lead & Lead & $\begin{array}{l}\text { Lead in the DEMIN model transfers some } \\
\text { lower-order management activities to the } \\
\text { Coordination Center and focuses on } \\
\text { higher-order activities }\end{array}$ \\
\hline \multirow{3}{*}{$\begin{array}{l}\text { Proximity to } \\
\text { Market }\end{array}$} & Contributor & Contributor & $\begin{array}{l}\text { Contributors in the DEMIN model lose } \\
\text { lower-order management activities } \\
\text { related to production, but gain relevance } \\
\text { as a link to the market, contributing to the } \\
\text { development of systems, processes, } \\
\text { products }\end{array}$ \\
\hline & Source & & $\begin{array}{l}\text { Source Plants become Contributor Plants } \\
\text { or Customization Centers depending on } \\
\text { their original characteristics }\end{array}$ \\
\hline & & $\begin{array}{l}\text { Lightweight } \\
\text { Customization } \\
\text { or Service } \\
\text { Center }\end{array}$ & $\begin{array}{l}\text { A new type of Site, agile, flexible to } \\
\text { provide customized goods and services } \\
\text { according to customers' requirements }\end{array}$ \\
\hline
\end{tabular}

\section{Pieces of evidence}

In this section, we provide empirical evidence to our Statements, analytical model, and taxonomy. There is evidence in the business literature that supports Statement 1 about the integration of systems and functions. Traditional manufacturers like Procter \& Gamble decided to create Regional planning centers in Costa Rica for America, Poland for Europe, and Singapore for Asia (Cosmetics Technology, 2014; P\&G, 2010, 2019; Sentence, 2018). Other companies that opened service centers to manage regional or International Operations Management are Bayer (Alvarado, 2018), Roche 
(Costa Rican Investment Promotion Agency, 2018), and Hewlett Packard (Costa Rican Investment Promotion Agency, 2019). Rolls Royce has a data center in the UK that monitors the operations of thousands of aircraft engines around the world in real-time (Marketing Derby, 2017). In the same way, Boeing keeps around-the-clock monitoring center in Everett, Washington, US, to track the global 787 Dreamliner fleet (Boeing, 2019).

The business literature also provides a few examples of how firms are managing their R\&D activities in the Digital Transformation era. P\&G recently opened Global and Regional Innovation Centers in the US for North America, Brazil for Latin America, Warshaw for Europe, and Singapore for Asia, some co-located with production Sites, others as stand-alone operations (Carnevalli, 2019; Chan, 2017; Coolidge, 2019; P\&G, 2019). The digital innovation center in Singapore is designed to research and develop new digital solutions for the company (Chan, 2017). IBM announced a new Artificial Intelligence R\&D center in Brazil that will join one already existing one in India and its other centers located in the US (Brigatto, 2019). GE has specialized R\&D centers in the US, India, China, Germany, and Brazil that aim to foster local innovation while making the results available for its global network (GE, 2014). GE's Brazil R\&D center, for example, locates in the city of Rio de Janeiro, works closely with Petrobrás, with a common "[...] focus on developing advanced subsea oil and gas technology" (GE, 2014). This last example suggests that R\&D centers can also be located closer to strategic clients or markets.

Statement 2 tackles the phenomenon of servitization, integrating both manufacturing and services operations. In the next paragraphs, we illustrate how digital technologies are supporting the servitization transformation (Baines et al., 2020) in two cases well documented in the academic literature (Baines et al., 2009; Lightfoot et al., 2013).

The first case, Xerox, showcases the servitization transformation (Visintin, 2014). It started with an Industry 2.0 model of leasing the equipment and charging for the photocopies in the 1960s, evolved to an Industry 3.0 model where local networks of multifunctional printers were managed at each site by local representatives in the 1990s, and finally reached an Industry 4.0 model where Xerox manages the networks of their clients from centralized helpdesk offices, while customers can also access the networks from their offices, homes or any location around the globe (Visintin, 2014). Digital transformation also altered Xerox's business model, which now offers advanced business services like document management, human resources, reimbursement, accounting, and customer care services (Visintin, 2014; Yin et al., 2018).

The aircraft industry is another well-documented servitization case in academic literature, as pointed out by Lightfoot et al. (2013). It started in the late 1990s when American Airlines requested Rolls Royce to offer a package that would pay by the hour flown by an engine, a risky and potentially disadvantageous model for Rolls Royce by then (Baines \& Lightfoot, 2014). Only when technology enabled the construction of real-time CPS, connecting the in-flight engine, a centralized Coordination Center, and dispersed Lightweight Service Centers, would the model become profitable (Baines \& Lightfoot, 2014; Visintin, 2014). Today, Rolls Royce makes over $50 \%$ of its revenue out of services, coordinated from the central control center (Coordination Center) located at Derby, UK, while the service centers (Lightweight Service Centers) are dispersed at their customers' operational hubs like Texas, Singapore and Hong Kong (Baines \& Lightfoot, 2014). 
The apparel industry illustrates the phenomenon of reshoring that supports Statement 3. Nike reshored operations in 2013 and Adidas followed in 2017 by opening a new plant in Ansbach, Germany, and later a second one in the US. Adidas coined the concept of a "speed factory" to describe their new plants using technologies such as 3-D printing, collaborative robots, and automated systems to manufacture their customized products (European Foundation for the Improvement of Living and Working Conditions, 2019; Green, 2016; Lund et al., 2019; Wiener, 2017). The "store factory", on the other hand, is an Adidas' small customization center located in shopping malls that share the characteristics of Lightweight Service Centers in our proposed taxonomy. There, consumers can go in, design their apparel, have their measures taken with the support of a store employee, have the piece made in a few hours on the spot, and then take it right away. "Store factories" represent a new business model that may become predominant in the future apparel industry (Bertola \& Teunissen, 2018; Wiener, 2017). Finally, the apparel sector could benefit from digital platforms in several ways: the creation of fashion "smart networks" to develop new products (Bertola \& Teunissen, 2018) and consumers interacting with suppliers via e-commerce digital platforms to design and order their products, examples of digital platforms coordinated by Regional R\&D Centers (Gawer, 2014).

\section{Conclusions}

\subsection{Contributions}

The first contribution of this paper is to propose a model to bridge two areas of study in OM, Digital Transformation, and International Operations Management. We built a set of Statements derived from literature and an analytical model that added digital maturity as the third factor that defines plant roles and therefore the configuration and coordination of the IIN in the digital era. The second contribution is the development of an updated taxonomy for plant roles that considers the Digitally-Enabled Multinational Inner Network (DEMIN). The Statements and the DEMIN model were evidenced by cases found in the academic and business literature. We introduced cyber-physical systems and digital platforms as system integration and management tools for the Site and the IIN levels to better create and capture value from the ecosystems in which they are inserted.

\subsection{Managerial implications}

The higher integration of functions provided by Digital Transformation allows an expansion of Industry 3.0-based models. The new taxonomy suggests that access to knowledge and capabilities and proximity to market gain relevance against the access to low-cost production as drivers to localize plants, while R\&D, services, and sites that coordinate activities for the IIN are incorporated to the model, reflecting the higher integration provided by digital technologies. A firm may configure and coordinate its IIN in novel ways that cannot be foreseen with traditional models. Sites can use Digital Transformation to improve their capabilities, acquire new activities, and upgrade their role within their IINs. 


\subsection{Research limitations}

There are limitations to this research. The first one is that this is a theory-building paper that requires future systematic empirical validation. It is also a first attempt to theorize the complex relationships between Digital Transformation and International Operations Management.

Another question that deserves further investigation is how governments can prepare their countries and take advantage of the Digital Transformation. Platform Industrie 4.0 in Germany, Manufacturing USA and Made in China 2025 - MIC2025 are national programs that intend to create the necessary conditions to fulfill their strategic goals, typically with joint efforts from governments, firms, and academy (Arbix et al., 2017). Different strategic goals may apply. Germany, Japan, and South Korea are technology and manufacturing leaders; the USA, UK, and France want to recover their manufacturing capability; China with "MIC2025", and India with "Make in India" are emerging countries that want to catch up and consolidate themselves as new manufacturing and technology leaders (Freitas, 2018). Another strategy was taken by other countries like Costa Rica, a leader in regional or global services (Alvarado, 2018; Costa Rican Investment Promotion Agency, 2018, 2019; Cosmetics Technology, 2014), and Israel in ICT technology development (Breznitz, 2007).

\subsection{Future research}

The DEMIN model proposed in this article will be used in empirical case studies of national and foreign multinationals operating in Brazil. This will be an excellent opportunity to validate the analytical model and Statements besides verifying their generalization potential. We hope that the analytical model, Statements, and plant taxonomy presented in this paper may offer a lens for future studies about Digital Transformation, International Operations Management, and other research fields.

\section{Acknowledgments}

We thank the two reviewers and Luis Fernando Costa Oliveira for his insightful comments.

\section{References}

Adolphs, P., Bedenbender, H., Dirzus, D., Ehlich, M., Epple, U., Hankel, M., Heidel, R., Hoffmeister, M., Huhle, H., Kärcher, B., Koziolek, H., Pichler, R., Pollmeier, S., Schewe, F., Walter, A., Waser, B., \& Wollschlaeger, M. (2015). Reference architecture model industrie 4.0 (RAMI4.0). Frankfurt am Main: ZVEI.

Alcácer, V., \& Cruz-Machado, V. (2019). Scanning the Industry 4.0: a literature review on technologies for manufacturing systems. Engineering Science and Technology: an International Journal, 22(3), 899-919. http://dx.doi.org/10.1016/j.jestch.2019.01.006.

Alvarado, L. (2018, 19 february). Bayer opens new shared service center in Costa Rica and will hire 350 employees. The Costa Rica Star. Retrieved in 2019, March 28, from https://news.co.cr/bayer-opens-new-shared-service-center-costa-rica-will-hire-350employees/70776/ 
Ancarani, A., Di Mauro, C., \& Mascali, F. (2019). Backshoring strategy and the adoption of Industry 4.0: evidence from Europe. Journal of World Business, 54(4), 360-371. http://dx.doi.org/10.1016/j.jwb.2019.04.003.

Arbix, G., Salerno, M. S., Zancul, E., Amaral, G., \& Lins, L. M. (2017). O Brasil e a nova onda de manufatura avançada: o que aprender com Alemanha, China e Estados Unidos. Novos Estudos, 36(3), 28-49. http://dx.doi.org/10.25091/S01013300201700030003.

Baines, T. S., Lightfoot, H. W., Evans, S., Neely, A., Greenough, R., Peppard, J., Roy, R., Shehab, E., Braganza, A., Tiwari, A., Alcock, J. R., Angus, J. P., Bastl, M., Cousens, A., Irving, P., Johnson, M., Kingston, J., Lockett, H., Martinez, V., Michele, P., Tranfield, D., Walton, I. M., \& Wilson, H. (2007). State-of-the-art in product-service systems. Proceedings of the Institution of Mechanical Engineers. Part B, Journal of Engineering Manufacture, 221(10), 1543-1552. http://dx.doi.org/10.1243/09544054JEM858.

Baines, T., \& Lightfoot, H. (2014). Servitization in the aircraft industry: understanding advanced services and the implications of their delivery. In F. Visintin (Ed.), Servitization in industry (pp. 45-54). Cham: Springer. http://dx.doi.org/10.1007/978-3-319-06935-7_3.

Baines, T., Lightfoot, H., Peppard, J., Johnson, M., Tiwari, A., Shehab, E., \& Swink, M. (2009). Towards an operations strategy for product-centric servitization. International Journal of Operations \& Production Management, 29(5), 494-519. http://dx.doi.org/10.1108/01443570910953603.

Baines, T., Ziaee Bigdeli, A., Bustinza, O. F., Shi, V. G., Baldwin, J., \& Ridgway, K. (2017). Servitization: revisiting the state-of-the-art and research priorities. International Journal of Operations \& Production Management, 37(2), 256-278. http://dx.doi.org/10.1108/IJOPM06-2015-0312.

Baines, T., Ziaee Bigdeli, A., Sousa, R., \& Schroeder, A. (2020). Framing the servitization transformation process: a model to understand and facilitate the servitization journey. International Journal of Production Economics, 221, 107463. http://dx.doi.org/10.1016/j.jpe.2019.07.036.

Barbieri, P., Ciabuschi, F., Fratocchi, L., \& Vignoli, M. (2018). What do we know about manufacturing reshoring? Journal of Global Operations and Strategic Sourcing, 11(1), 79122. http://dx.doi.org/10.1108/JGOSS-02-2017-0004.

Barbosa, M. T. J., Baiso, M., \& Almeida, M. T. (2018). Surge uma nova sociedade. In E. B. Silva, M. L. R. P. D. Scoton, E. M. Dias \& S. L. Pereira (Eds.), Automação \& sociedade: Quarta Revolução Industrial, um olhar para o Brasil (pp. 3-11). São Paulo: GAESI.

Bertola, P., \& Teunissen, J. (2018). Fashion 4.0. Innovating fashion industry through Digital Transformation. Research Journal of Textile and Apparel, 22(4), 352-369. http://dx.doi.org/10.1108/RJTA-03-2018-0023.

Boeing. (2019). 787 operations control center. Retrieved in 2019, March 28, from https://www.boeing.com/commercial/services/24-7-customer-support/operationscenters/\#/787-operations-control-center

Brennan, L., Ferdows, K., Godsell, J., Golini, R., Keegan, R., Kinkel, S., Srai, J. S., \& Taylor, M. (2015). Manufacturing in the world: where next? International Journal of Operations \& Production Management, 35(9), 1253-1274. http://dx.doi.org/10.1108/IJOPM-03-20150135.

Breznitz, D. (2007). Industrial R\&D as a national policy: horizontal technology policies and industry-state co-evolution in the growth of the Israeli software industry. Research Policy, 36(9), 1465-1482. http://dx.doi.org/10.1016/j.respol.2007.06.006.

Brigatto, G. (2019, 17 june). IBM terá centro de pesquisa no Brasil. Jornal Valor Econômico. Retrieved in 2019, March 28, from https://www.valor.com.br/empresas/6115859/ibm-teracentro-de-pesquisa-no-brasil

Carnevalli, E. (2019, 7 may). Procter \& Gamble inaugura primeiro centro de inovação na América Latina. Época Negócios. Retrieved in 2019, March 28, from 
https://epocanegocios.globo.com/Empresa/noticia/2019/05/procter-gamble-inauguraprimeiro-centro-de-inovacao-na-america-latina.html

Casella, B., \& Formenti, L. (2019). UNCTAD insights: FDI in the digital economy: a shift to asset-light international footprints. Transnational Corporations, 25(1), 101-130. http://dx.doi.org/10.18356/cb688e94-en.

Chan, S. (2017, 19 april). Procter \& Gamble to invest US\$100m in Singapore digital innovation centre. The Straits Times. Retrieved in 2019, March 28, from https://www.straitstimes.com/business/economy/procter-gamble-to-invest-us100m-insingapore-digital-innovation-centre-its-first

Cheng, Y., Farooq, S., \& Johansen, J. (2011). Manufacturing network evolution: a manufacturing plant perspective. International Journal of Operations \& Production Management, 31(12), 1311-1331. http://dx.doi.org/10.1108/01443571111187466.

Cheng, Y., Farooq, S., \& Johansen, J. (2015). International manufacturing network: past, present, and future. International Journal of Operations \& Production Management, 35(3), 392-429. http://dx.doi.org/10.1108/JJOPM-03-2013-0146.

Coolidge, A. (2019, May 15). P\&G unveils its largest R\&D center in the world: it's in Mason, Ohio. Cincinnati Enquirer. Retrieved in 2019, March 28, from https://www.cincinnati.com/story/money/2019/05/15/p-g-unveils-its-largest-r-d-center-worldits-mason-ohio/3674512002/

Cosmetics Technology. (2014, 30 june). P\&G opens Latin American Supply Chain Planning center in Costa Rica. Retrieved in 2019, March 28, from https://www.cosmeticstechnology.com/news/newspg-opens-latin-american-supply-chain-planning-center-in-costarica-4306408/

Costa Rican Investment Promotion Agency - CINDE. (2018, 18 january). Roche inaugurates new IT Global Shared Service Center in Costa Rica. San Jose. Retrieved in 2019, March 28 , from https://www.cinde.org/en/news/press-release/roche-inaugurates-new-it-globalshared-service-center-in-costa-rica

Costa Rican Investment Promotion Agency - CINDE. (2019). Success stories: Hewlett Packarad Enterprise. San Jose. Retrieved in 2019, March 28, from https://www.cinde.org/en/sectors/services/success-stories

Demeter, K. (2017). Research in Global Operations Management: some highlights and potential future trends. Journal of Manufacturing Technology Management, 28(3), 324-333. http://dx.doi.org/10.1108/JMTM-02-2017-0030.

Drath, R., \& Horch, A. (2014). Industrie 4.0: hit or hype? [industry forum]. IEEE Industrial Electronics Magazine, 8(2), 56-58. http://dx.doi.org/10.1109/MIE.2014.2312079.

European Foundation for the Improvement of Living and Working Conditions - Eurofound. (2019). Reshoring case: Adidas. Retrieved in 2019, March 28, from https://reshoring.eurofound.europa.eu/reshoring-cases/adidas

Feldmann, A., \& Olhager, J. (2013). Plant roles: site competence bundles and their relationships with site location factors and performance. International Journal of Operations \& Production Management, 33(6), 722-744. http://dx.doi.org/10.1108/IJOPM-03-20110077.

Feldmann, A., Olhager, J., Fleet, D., \& Shi, Y. (2013). Linking networks and plant roles: the impact of changing a plant role. International Journal of Production Research, 51(19), 5696-5710. http://dx.doi.org/10.1080/00207543.2013.778429.

Ferdows, K. (1997). Making the most of foreign factories. Harvard Business Review, 75, 73-91.

Fleury, A. C. C., \& Fleury, M. T. L. (2012). Multinacionais brasileiras: competências para a internacionalização. Rio de Janeiro: FGV Editora. 
Frank, A. G., Dalenogare, L. S., \& Ayala, N. F. (2019a). Industry 4.0 technologies: implementation patterns in manufacturing companies. International Journal of Production Economics, 210, 15-26. http://dx.doi.org/10.1016/j.jpe.2019.01.004.

Frank, A. G., Mendes, G. H., Ayala, N. F., \& Ghezzi, A. (2019b). Servitization and Industry 4.0 convergence in the Digital Transformation of product firms: a business model innovation perspective. Technological Forecasting and Social Change, 141, 341-351. http://dx.doi.org/10.1016/j.techfore.2019.01.014.

Freitas, M. C. P. (2018). Estratégias nacionais para a Indústria 4.0. In Instituto de Estudos para o Desenvolvimento Industrial - IEDI, Indústria e o Brasil do futuro (pp. 202-219). São Paulo.

Gawer, A. (2014). Bridging differing perspectives on technological platforms: toward an integrative framework. Research Policy, 43(7), 1239-1249. http://dx.doi.org/10.1016/j.respol.2014.03.006.

GE. (2014, 13 november). GE opens new global R\&D center in Brazil. Retrieved in 2019, March 28, from https://www.genewsroom.com/press-releases/ge-opens-new-global-rd-centerbrazil-279220

Govindarajan, V., \& Immelt, J. R. (2019). The only way manufacturers can survive. MIT Sloan Management Review, 60(3), 24-33.

Green, T. (2016, 13 june). Adidas comes home to build a robot-driven "speed factory". Robotics Business Review. Retrieved in 2019, March 28, from https://www.roboticsbusinessreview.com/manufacturing/adidas-comes-home-build-robotdriven-speed-factory/

Kagermann, H., Helbig, J., Hellinger, A., \& Wahlster, W. (2013). Recommendations for implementing the strategic initiative Industrie 4.0: securing the future of German manufacturing industry; final report of the Industrie 4.0 Working Group. Berlin: Forschungsunion.

Kinkel, S. (2012). Trends in production relocation and backshoring activities: changing patterns in the course of the global economic crisis. International Journal of Operations \& Production Management, 32(6), 696-720. http://dx.doi.org/10.1108/01443571211230934.

Liao, Y., Deschamps, F., Loures, E. D. F. R., \& Ramos, L. F. P. (2017). Past, present and future of Industry 4.0: a systematic literature review and research agenda proposal. International Journal of Production Research, 55(12), 3609-3629. http://dx.doi.org/10.1080/00207543.2017.1308576.

Liao, Y., Loures, E. R., Deschamps, F., Brezinski, G., \& Venâncio, A. (2018). The impact of the fourth industrial revolution: a cross-country/region comparison. Production, 28, e20180061. http://dx.doi.org/10.1590/0103-6513.20180061.

Lichtblau, K., Stich, V., Bertenrath, R., Blum, M., Bleider, M., Millack, A., \& Schröter, M. (2015). IMPULS-industrie 4.0-readiness. Aachen-Köln: Impuls-Stiftung des VDMA.

Lightfoot, H., Baines, T., \& Smart, P. (2013). The servitization of manufacturing: a systematic literature review of interdependent trends. International Journal of Operations \& Production Management, 33(11-12), 1408-1434. http://dx.doi.org/10.1108/IJOPM-07-2010-0196.

Lund, S., Manyika, J., Woetzel, J., Bughin, J., Krishnan, M., Seong, J., \& Muir, M. (2019). Globalization in transition: the future of trade and value chains. McKinsey Global Institute. Retrieved in 2019, March 28, from https://www.mckinsey.com/featured-insights/innovationand-growth/globalization-in-transition-the-future-of-trade-and-value-chains

Marketing Derby. (2017, 8 june). New data centre for Rolls Royce. Retrieved in 2019, March 28, from https://www.marketingderby.co.uk/news-library/2017/6/8/new-data-centre-for-rollsroyce

Martinez, V., Bastl, M., Kingston, J., \& Evans, S. (2010). Challenges in transforming manufacturing organisations into product-service providers. Journal of Manufacturing Technology Management, 21(4), 449-469. http://dx.doi.org/10.1108/17410381011046571. 
Meijboom, B., \& Vos, B. (2004). Site competence dynamics in international manufacturing networks: instrument development and a test in Eastern European factories. Journal of Purchasing and Supply Management, 10(3), 127-136.

http://dx.doi.org/10.1016/j.pursup.2004.09.001.

P\&G. (2010, 24 december). The strategy is simple... Retrieved in 2019, March 28, from https://news.pg.com/blog/company-strategy/strategy-simple\%E2\%80\%A6.

P\&G. (2019). P\&G in Poland. Retrieved in 2019, March 28, from https://www.pgcareers.com/location-poland

Rodrigues, L. F., Jesus, R. A., \& Schützer, K. (2016). Industrie 4.0: uma revisão da literatura. Revista de Ciencia y Tecnología, 19(38), 33-45. http://dx.doi.org/10.15600/22381252/rct.v19n38p33-45.

Rudberg, M., \& Olhager, J. (2003). Manufacturing networks and supply chains: an operations strategy perspective. Omega, 31(1), 29-39. http://dx.doi.org/10.1016/S03050483(02)00063-4.

Rugman, A., Verbeke, A., \& Yuan, W. (2011). Re-conceptualizing Bartlett and Ghoshal's classification of national subsidiary roles in the multinational enterprise. Journal of Management Studies, 48(2), 253-277. http://dx.doi.org/10.1111/j.1467-6486.2010.00969.x.

Schuh, G., Anderl, R., Gausemeier, J., ten Hompel, M., \& Wahlster, W. (2017). Industrie 4.0 maturity index: managing the digital transformation of companies. Munich: Herbert Utz.

Schumacher, A., Erol, S., \& Sinn, W. (2016). A maturity model for assessing Industry 4.0 readiness and maturity of manufacturing enterprises. Procedia Cirp, 52, 161-166. http://dx.doi.org/10.1016/j.procir.2016.07.040.

Schwab, K. (2017). The fourth industrial revolution. London: Penguin Books.

Seino, N. (2019). SAP Global LCM services to realize global operation and maintenance. Fujitsu Scientific and Technical Journal, 55(1), 59-63.

Sentence, R. (2018, November 23). How P\&G is accelerating Digital Transformation in Singapore. Econsultancy. Retrieved in 2019, March 28, from https://econsultancy.com/digital-transformation-news-singapore-dell-mclaren-futurehealthcare/

Shi, Y., \& Gregory, M. (1998). International manufacturing networks: to develop global competitive capabilities. Journal of Operations Management, 16(2-3), 195-214. http://dx.doi.org/10.1016/S0272-6963(97)00038-7.

Strange, R., \& Zucchella, A. (2017). Industry 4.0, global value chains and international business. Multinational Business Review, 25(3), 174-184. http://dx.doi.org/10.1108/MBR05-2017-0028.

Taylor, F. W. (1998). The principles of scientific management. New York: Dover Publications.

Telukdarie, A., Buhulaiga, E., Bag, S., Gupta, S., \& Luo, Z. (2018). Industry 4.0 implementation for multinationals. Process Safety and Environmental Protection, 118, 316-329. http://dx.doi.org/10.1016/j.psep.2018.06.030.

Vandermerwe, S., \& Rada, J. (1988). Servitization of business: adding value by adding services. European Management Journal, 6(4), 314-324. http://dx.doi.org/10.1016/02632373(88)90033-3.

Vasconcelos Gomes, L. A., Facin, A. L. F., Salerno, M. S., \& Ikenami, R. K. (2018). Unpacking the innovation ecosystem construct: evolution, gaps and trends. Technological Forecasting and Social Change, 136, 30-48. http://dx.doi.org/10.1016/j.techfore.2016.11.009.

Vereecke, A., \& Van Dierdonck, R. (2002). The strategic role of the plant: testing Ferdows's model. International Journal of Operations \& Production Management, 22(5), 492-514. http://dx.doi.org/10.1108/01443570210425147. 
Visintin, F. (2014). Photocopier industry: at the forefront of servitization. In F. Visintin (Ed.), Servitization in industry (pp. 23-43). Cham: Springer. http://dx.doi.org/10.1007/978-3-31906935-7_2.

Wiener, A. (2017). Fast break: inside Adidas' robot-powered, on-demand sneaker factory. Wired, 25(12), 85-92.

Yin, Y., Stecke, K. E., \& Li, D. (2018). The evolution of production systems from Industry 2.0 through Industry 4.0. International Journal of Production Research, 56(1-2), 848-861. http://dx.doi.org/10.1080/00207543.2017.1403664. 